ISSN: 2302-8556

E-Jurnal Akuntansi Universitas Udayana

Vol.24.2.Agustus (2018): 1503-1529

DOI: https://doi.org/10.24843/EJA.2018.v24.i02.p25

\title{
Pengaruh Konservatisme Akuntansi, Good Corporate Governance dan Pertumbuhan Perusahaan Pada Earnings Response Coefficient
}

\author{
Ni Made Aristawati ${ }^{1}$ \\ Ni Ketut Rasmini ${ }^{2}$
}

${ }^{1}$ Fakultas Ekonomi dan Bisnis Universitas Udayana (Unud), Bali, Indonesia
email: wati.arista @ rocketmail.com/ telp: +6281999118825
${ }^{2}$ Fakultas Ekonomi dan Bisnis Universitas Udayana (Unud), Bali, Indonesia

\begin{abstract}
ABSTRAK
Kualitas laba penting bagi pengguna laporan keuangan untuk tujuan kontrak dan pengambilan keputusan investasi. Earnings Response Coefficient adalah salah satu metode yang digunakan untuk mengukur kualitas laba. Tujuan dari penelitian ini adalah untuk mengetahui pengaruh konservatisme akuntansi, Good Corporate Governance dan pertumbuhan perusahaan pada Earnings Response Coefficient. Penelitian ini menggunakan data sekunder pada perusahaan yang terdaftar di BEI dan masuk pemeringkatan IICG pada tahun 2011-2015. Teknik penentuan sampel menggunakan metode purposive sampling dan diperoleh sebanyak 6 sampel dengan pengamatan lima tahun menjadi 30 observasian. Teknik analisis data yang digunakan adalah analisis regresi linier berganda.

Hasil analisis menunjukkan bahwa konservatisme akuntansi berpengaruh positif pada ERC. Sedangkan variabel GCG dan pertumbuhan perusahaan tidak berpengaruh pada ERC. Penelitian ini mendukung teori sinyal yang menjelaskan mengapa perusahaan mempunyai inisiatif dan dorongan untuk memberikan informasi kepada pihak eksternal. Hasil penelitian ini juga dapat digunakan sebagai referensi dan tambahan informasi bagi pihak yang berkepentingan.
\end{abstract}

Kata kunci: Good Corporate Governance, Earnings Response Coefficient, konservatisme akuntansi, pertumbuhan perusahaan.

\begin{abstract}
Quality of profit is important for users of financial statements for the purposes of contracting and investment decision making. Earnings Response Coefficient is one of the methods used to measure earnings quality. The purpose of this study is to determine the effect of accounting conservatism, Good Corporate Governance and corporate growth on Earnings Response Coefficient. This study uses secondary data on companies listed on the IDX and entered IICG ranking in 2011-2015. The technique of determining the sample using purposive samplin $g$ and obtained by 6 samples with observation of five years to 30 observation. Data analysis technique used is multiple linear regression analysis.

The results show that accounting conservatism has a positive effect on ERC. While the GCG variable and the company's growth has no effect on ERC. This study supports the signal theory that explains why firms have the initiative and drive to provide information to external parties. The results of this study can also be used as a reference and additional information for interested parties.
\end{abstract}

Keywords: Good Corporate Governance, Earnings Response Coefficient, accounting conservatism, corporate growth. 


\section{PENDAHULUAN}

Laporan keuangan memiliki peran penting dalam suatu perusahaan seperti halnya dapat menjadi media informasi dalam merangkum aktivitas suatu perusahaan yang menunjukkan kemampuan perusahaan atau menjadi indikator perusahaan mengelola sumber dayanya. Hasil penelitian Beaver et al. (1979) dalam Murwaningsari (2008) menyatakan harga saham mencerminkan laba perusahaan memiliki kandungan informasi. Selain itu informasi laba di dalam laporan keuangan dapat dipandang sebagai elemen yang cukup kaya (komprehensif) untuk menunjukkan kinerja suatu perusahaan hal ini dapat menjadi perhatian investor dalam mengambil suatu keputusan (Putri, 2015).

Reaksi pasar dapat ditunjukkan melalui tindakan pelaku pasar dalam membuat keputusan ekonomi berdasarkan informasi laporan keuangan (Wulandari \& Suprasto, 2015). Melalui pengumuman laba reaksi pasar dapat diamati. Laba akuntansi digunakan dalam menilai suatu emiten dengan melihat hubungan laba akuntansi dan return. Laba akuntansi suatu emiten dikatakan memiliki kandungan informasi apabila laba dengan returnnya memiliki suatu hubungan (Suaryana, 2005). Hubungan harga saham dengan laba dapat dinilai melalui penelitian earnings response coefficient, menurut Park \& Pincus (2001) coefficient tersebut dapat dijadikan sebagai tolak ukur sensitifitas return ekuitas pada laba kejutan.

Palupi (2006) dalam penelitiannya menyatakan bahwa earnings response coefficient sangat penting bagi para investor untuk mengambil keputusan investasi terkait informasi laba dengan return. Secara teoritis Earnings Response 
Coefficient (ERC) dipakai untuk mengukur tingkat abnormal return sekuritas sebagai respon terhadap komponen laba kejutan (unexpected earnings) yang menerbitkan sekuritas tersebut (Scott, 2009). Ball \& Brown (1968) menyatakan mengenai analisis kandungan informasi bila unexpected earnings positif maka memiliki abnormal rate of return rata-rata positif (good news bagi investor) dan bila tidak memiliki informasi atau negatif maka abnormal rate of return rata-rata negatif (bad news bagi investor).

Perilaku investor merespon perubahan harga saham dapat dipengaruhi oleh sinyal melalui informasi yang diberikan pihak perusahaan (Spence, 1973). Signaling Theory menyatakan bahwa pemilik perusahaan memiliki sifat sukarela dalam melaporkan informasi perusahaan kepada pasar (Astika, 2011). Melalui pengungkapan informasi keuangan perusahaan, hal tersebut dapat mencerminkan informasi publik oleh pihal eksternal perusahaan khususnya investor (Rahayu, 2008). Murwaningsari (2008) menguji keterkaitan pengungkapan sukarela terhadap earnings response coefficient, mengungkapkan temuan yang sama dengan Kartadjumena (2010) yang menyatakan luas pengungkapan sukarela memiliki pengaruh positif pada ERC. Cho \& Jung (1991) mengidentifikasi secara teori menjadi 2 bagian, seperti model penilaian informasi ekonomi seperti yang dikembangkan Lev (1989) menunjukkan kuatnya respon investor terhadap sinyal informasi laba menunjukkan sesuatu yang tak pasti dimasa mendatang dan time series based valuation model sejalan dengan penelitian oleh Braver, Lambert \& Morse (1980) dalam Murwaningsari (2008). 
Ni Made Aristawati dan Ni Ketut Rasmini. Pengaruh...

Accounting conservatism adalah suatu reaksi yang bersifat kehati-hatian (prudent reaction) dalam menghadapi risiko yang tidak pasti (Ratna, 2004). Accounting conservatism menyatakan suatu prinsip penilaian yang berpengaruh pada praktik akuntansi selama beberapa abad serta memiliki konvensi yang penting bagi pelaporan perusahaan (Sterling, 1967; Basu,1997 dalam Ratnadi \& Ulupui, 2016). Accounting conservatism juga memiliki arti salah satu metode yang dipilih agar tetap menjaga nilai buku dari net assets relatif rendah (Penman \& Zhang, 2002).

Prinsip akuntansi konservatif ini mendatangkan pro dan kontra. Penelitian yang dilakukan oleh Natalia \& Ratnadi (2017), Diantimala (2008) menemukan bahwa terdapat pengaruh negatif pada hubungan antara konservatisme akuntansi dengan ERC. Berbeda dengan penelitian yang dilakukan oleh Tuwentina \& Wirama (2014), Rahayu (2012) serta Setyaningtyas (2009) mengungkapkan adanya pengaruh positif antara konservatisme akuntansi dengan ERC. Penerapan laporan keuangan yang konservatif bermanfaat untuk penyajian laba perusahaan yang agar tidak overstated (Hersanti, 2008). Melaui penerapan pelaporan akuntansi yang konservatif, hal tersebut akan bermanfaat dalam meminimalisasi sifat berlebihan pihak manajemen perusahaan yang ingin melakukan kecurangan terhadap laba (Fala, 2007 dalam Noviantari \& Ratnadi, 2015).

Penerapan Good Corporate Governance (GCG) dapat menjadi sinyal yang diberikan perusahaan terhadap pihak eksternal perusahaan sehingga meningkatkan nilai pasar. Manajemen yang ingin menunjukan kinerja yang baik dapat termotivasi untuk memanipulasi laporan keuangan agar bisa mencapai laba seperti 
yang diinginkan oleh pemilik (Sari \& Putri, 2014). Bistrova \& Lace (2012) menyatakan bahwa perusahaan akan meminimalisasi adanya manipulasi laporan keuangan apabila mempunyai tata kelola yang baik. GCG dapat meningkatkan kinerja perusahaan melalui pengawasan kinerja manajemen serta menjamin terciptanya akuntabilitas manajemen terhadap pihak investor berdasarkan peraturan yang ada (Kori \& Rasmini, 2017). Neal \& Cochran (2008) menyatakan bahwa penerapan GCG sangat bernilai terhadap pasar modal yang akan mempengaruhi pasar, sejalan dengan hal tersebut investorpun akan rela dalam membayar lebih atas perusahaan-perusahaan yang menerapkan prinsip-prinsip corporate governance.

Penerapan GCG pada perusahaan membuat perusahaan lebih dipercaya sehingga respon pasar terhadap laba dipengaruhi oleh buruk atau baiknya corporate governance badan usaha yang mengumumkan laba (Wulandari \& Suprasto, 2015). Pemeringkatan penerapan corporate governance di Indonesia untuk perusahaan-perusahaan yang tercatat di Bursa Efek Indonesia (BEI) dinilai oleh The Indonesian Institute for Corporate Governance (IICG) dengan nama Corporate Governance Perception Index (CGPI). Oleh karena itu proksi GCG pada penelitian ini menggunakan CGPI sebab perusahaan yang menerapkan good corporate governance akan merujuk pada respon positif investor terhadap penyampaian informasi oleh perusahaan.

Beberapa hasil penelitian mengenai pengaruh GCG pada ERC menunjukkan hasil yang bervariasi. Penelitian yang dilakukan oleh Tuwentina \& Wirama (2014) menemukan bahwa GCG tidak berpengaruh pada kualitas laba 
Ni Made Aristawati dan Ni Ketut Rasmini. Pengaruh...

yang pengukurannya menggunakan ERC. Penelitian yang dilakukan oleh Indrawati \& Yulianti (2010) meneliti pengaruh 4 mekanisme GCG pada ERC yang menunjukkan hasil bahwa kepemilikan institusional saja yang berpengaruh pada kualitas laba sedangkan variabel lainnya tidak berpengaruh. Berbeda dengan penelitian yang dilakukan oleh Wati \& Putra (2017), Wulandari \& Suprasto (2015) serta Rifani (2013) yang menemukan GCG memiliki pegaruh positif pada terhadap ERC. Semakin baik tingkat GCG yang dimiliki suatu perusahaan maka akan memperlemah tindakan agen dalam melakukan manipulasi laba yang bersifat merugikan sehingga dapat memberikan respon yang positif. Penelitian yang dilakukan oleh Wirajaya (2009) dalam Wulandari \& Suprasto (2015) juga menemukan bahwa pengumuman CGPI memiliki kandungan informasi sehingga direaksi oleh pasar yang ditunjukkan dengan adanya abnormal return yang signifikan disekitar tanggal pengumuman.

Penelitian mengenai relasi antara return/earnings memperlihatkan bahwa kegunaan dari informasi laba yang dipakai investor masih sangat terbatas (Sayekti \& Wondabio, 2007). Hal ini mendorong untuk menguji salah satu faktor yang dapat mempengaruhi reaksi pasar terhadap informasi laba selain kualitas laba yang memiliki pengaruh pada respon investor dalam mengambil keputusan adalah pertumbuhan perusahaan. Pertumbuhan perusahaan merupakan salah satu pertimbangan investor ketika berinvestasi (Sari, 2012). Perusahaan yang terus bertumbuh akan dengan mudah dalam mendapatkan modal bagi perusahaan dan ini dapat menjadi sumber pertumbuhan. Informasi laba pada perusahaan yang terus bertumbuh akan direspon oleh investor. 
Collins \& Khotari (1989) mengungkapkan pertumbuhan dan ERC memiliki pengaruh yang positif. Perusahaan bertumbuh akan miliki ERC yang lebih tinggi, hal ini dikarenakan adanya peningkatan respon pasar yang berasal dari kandungan informasi berupa laba menjadikan hal tersebut kabar yang baik sehingga perusahaan memiliki kesempatan yang lebih tinggi di masa mendatang dalam memperoleh laba (Setiawati \& Nursiam, 2014). Semakin meningkat perusahaan tersebut tumbuh maka semakin berkualitas pula laba yang dihasilkan perusahaan. Penelitian oleh Reyhan (2014), Naimah \& Utama (2006), Charitou et al. (2001) serta Collins \& Khotari (1989) menemukan hubungan positif pertumbuhan perusahaan dengan ERC. Berbeda dengan penelitian yang dilakukan oleh Irawati (2012) serta Sugiarto \& Siagian (2007) dalam temuannya menyatakan pertumbuhan perusahaan memiliki pengaruh negatif terhadap ERC. Penelitian-penelitian sebelumnya menunjukkan bahwa faktor-faktor yang disebutkan di atas tampak relevan dengan ERC serta masih adanya hasil penelitian yang berbeda-beda menyebabkan peneliti ingin menguji kembali untuk mendapatkan tambahan bukti empiris atas penelitian sebelumnya mengenai pengaruh konservatisme akuntansi, GCG dan pertumbuhan perusahaan pada respon pasar yang ditunjukkan oleh nilai ERC.

Tujuan dari dilakukannya penelitian ini untuk memperoleh bukti empiris pengaruh konservatisme akuntansi terhadap earnings response coefficient, untuk memperoleh bukti empiris pengaruh good corporate governance pada earnings response coefficient, dan untuk memperoleh bukti empiris pengaruh pertumbuhan perusahaan pada earnings response coefficient. Kegunaan penelitian ini secara 
Ni Made Aristawati dan Ni Ketut Rasmini. Pengaruh...

teoritis dapat memberikan wawasan mengenai teori sinyal serta membantu dalam memberikan bukti empiris mengenai pengaruh konservatisme akuntansi, good corporate governance dan pertumbuhan perusahaan pada earnings response coefficient bagi pihak-pihak yang berkepentingan. Secara praktis hasil dari penelitian ini diharapkan dapat memberikan sumbangan informasi dan bahan referensi sebagai bahan pertimbangan dalam rangka meningkatkan kualitas laba pada suatu perusahaan.

Kajian pustaka dalam penelitian ini menggunakan teori sinyal yang mengungkapkan alasan suatu emiten mempunyai keinginan untuk menginformasikan secara sukarela walaupun tidak wajib dalam pelaporan keuangan (Wolk et al., 2001). Signaling Theory menunjukkan adanya asimetri informasi antara manajemen dengan pihak-pihak yang berkepentingan dengan informasi tertentu. Konservatisme akuntansi berperan dalam teori sinyal dengan mencegah asimetri informasi dengan menyajikan laba yang tidak overstated. Perusahaan yang menerapkan akuntansi yang konservatif juga berguna dalam menghindari konflik antara kepentingan kreditor dengan kepentingan investor.

Penelitian yang dilakukan oleh Tuwentina \& Wirama (2014) menyatakan bahwa konservatisme akuntansi berpengaruh positif terhadap earnings response coefficient. Sejalan dengan temuan yang dilakukan Rahayu (2012) mengungkapkan konservatisme akuntansi memiliki pengaruh signifikan pada earnings response coefficient. Diperkuat dengan penelitian yang dilakukan oleh Setyaningtyas (2009) yang menemukan hubungan positif antara konservatisme 
akuntansi dan earnings response coefficient. Berdasarkan kerangka pemikiran dan hasil riset tersebut, maka hipotesis pertama penelitian ini yaitu:

$\mathrm{H}_{1}$ : Konservatisme akuntansi berpengaruh positif pada earnings response coefficient.

Mekanisme yang diharapkan dapat memberikan sinyal terhadap pihak yang berkepentingan yaitu dengan penerapan GCG. GCG dapat meningkatkan kepercayaan investor dan kreditur dalam berinvestasi. GCG juga dapat meningkatkan kinerja perusahaan melalui pengawasan kinerja manajemen serta menjamin terciptanya akuntabilitas manajemen terhadap pihak investor. Perusahaan yang menerapkan prinsip GCG akan meminimalisir kecurangan dalam pelaporan keuangan perusahaan.

Penelitian mengenai GCG melalui pemeringkatan IICG terhadap earnings response coefficient telah dilakukan oleh Wati \& Putra (2017) menyatakan GCG memiliki pengaruh positif pada ERC. Penelitian yang dilakukan oleh Wulandari \& Suprasto (2015) menunjukkan GCG berpengaruh positif terhadap earnings response coefficient. Rifani (2013) juga melakukan penelitian hasilnya GCG berpengaruh positif pada earnings response coefficient. Berdasarkan kerangka pemikiran dan hasil riset tersebut, maka hipotesis kedua penelitian ini yaitu:

$\mathrm{H}_{2}$ : Good Corporate Governance berpengaruh positif pada earnings response coefficient.

Temuan atau penelitian mengenai hubungan pertumbuhan perusahaan dengan earnings response coefficient telah banyak dilakukan. Penelitian yang dilakukan oleh Reyhan (2014), Naimah \& Utama (2006), Charitou et al. (2001) serta Collins \& Khotari (1989) menemukan hubungan positif pertumbuhan 
Ni Made Aristawati dan Ni Ketut Rasmini. Pengaruh...

perusahaan dengan ERC. Pertumbuhan perusahaan dapat menjadi pertimbangan investor ketika berinvestasi. Perusahaan yang memiliki kesempatan bertumbuh terhadap labanya berarti kinerja keuangan perusahaan tersebut baik dan dimungkinkan juga memiliki kesempatan bertumbuh terhadap kualitas labanya (Irawati, 2012) Perusahaan yang sedang bertumbuh akan cenderung memilih sumber dana eksternal melalui utang karena dipandang lebih murah dan lebih aman, selain itu perusahaan dapat terhindar dari konflik-konflik keagenan yang seringkali muncul dari penggunaan dana ekuitas.

Semakin besar tingkat kesempatan bertumbuh perusahaan akan semakin tinggi pula kesempatan perusahaan dalam mendapatkan laba oleh perusahaan di masa mendatang. Laba akuntansi memiliki pengaruh terhadap tingkat harga saham, harga saham yang tinggi dialami oleh perusahaan yang memiliki pertumbuhan yang tinggi dibandingkan dengan perusahaan yang mengalami tingkat bertumbuh yang rendah (Setiawati \& Nursiam, 2014). Berdasarkan kerangka pemikiran dan hasil riset tersebut, maka hipotesis ketiga penelitian ini yaitu:

$\mathrm{H}_{3}$ : Pertumbuhan perusahaan berpengaruh positif pada earnings response coefficient.

\section{METODE PENELITIAN}

Penelitian ini menggunakan pendekatan kuantitatif berbentuk penelitian asosiatif dengan hubungan kausal. Penelitian ini dilakukan pada perusahaan yang terdaftar di Bursa Efek Indonesia (BEI), perusahaan yang tercatat ikut pemeringkatan oleh IICG. Data yang digunakan berupa laporan keuangan perusahaan dan data harga 
saham. Obyek penelitiannya adalah earnings response coefficient dijelaskan dari konservatisme akuntansi, good corporate governance dan pertumbuhan perusahaan periode tahun 2011-2015. Dalam penelitian ini terdapat dua variabel yang diteliti yaitu variabel bebas dan variabel terikat. Variabel bebas dalam penelitian ini adalah $\mathrm{X}_{1}=$ konservatisme akuntansi, $\mathrm{X}_{2}=$ good corporate governance. Variabel terikat dalam penelitian ini adalah earnings response coefficient.

Earnings Response Coefficient ditunjukkan melalui variasi perusahaan reaksi pasar atas hubungan laba dengan return sekuritas, dengan kata lain coefficient dari regresi proksi harga saham dengan laba akuntansi (Nayar \& Rozeff, 1992). Cummulative Abnormal Return (CAR) digunakan sebagai proksi harga saham, Unexpected Return (UE) digunakan sebagai proksi laba akuntansi (Chaney \& Jeter, 1991). Konservatisme akuntansi diproksikan oleh indeks konservatisme yang diperoleh dari selisih antara laba bersih dengan aliran kas operasi yang kemudian dikurangi dengan depresiasi dibagi dengan total asset. Hasil yang diperoleh kemudian dikalikan dengan minus satu (Ahmed et al., 2000). GCG menggunakan pemeringkatan yang dilakukan oleh IICG. Pertumbuhan perusahaan pada penelitian ini diestimasi melalui pertumbuhan penjualan perusahaan.

Populasi dalam penelitian ini adalah perusahaan yang terdaftar di Bursa Efek Indonesia tahun 2011-2015 serta mengikuti pemeringkatan yang dilakukan oleh IICG. Metode pengumpulan sampel pada penelitian ini menggunakan metode nonprobability sampling dengan teknik purposive sampling. Teknik purposive 
Ni Made Aristawati dan Ni Ketut Rasmini. Pengaruh...

sampling merupakan metode penentuan sampel dengan kriteria yang dikehendaki, dimana anggota sampel akan dipilih dapat mewakili sifat-sifat populasi. Kriterianya seperti perusahaan yang terdaftar di BEI dan masuk pemeringkat CGPI yang diberikan oleh IICG periode 2011-2015, serta perusahaan yang tidak mengalami kerugian selama periode pengamatan. Hal ini dikarenakan ERC merupakan respon investor atas perubahan yang terjadi hanya pada laba yang dilaporkan oleh perusahaan. Jumlah sampel yang digunakan adalah sebanyak 6 perusahaan. Dari 6 perusahaan tersebut dilakukan pengamatan sebanyak 5 tahun sehingga diperoleh sebanyak 30 amatan perusahaan.

Jenis data yang digunakan dalam penelitian ini adalah data kuantitatif yaitu laporan keuangan perusahaan yang terdaftar di Bursa Efek Indonesia serta data harga saham tahun 2011-2015. Sumber data yang digunakan dalam penelitian ini adalah data sekunder. Metode pengumpulan data yang digunakan dalam penelitian ini adalah metode dokumentasi yang merupakan metode pengumpulan data yang dilakukan oleh peneliti dengan cara memperoleh data dokumen berupa laporan keuangan perusahaan, data yang menjadi peserta pemeringkatan IICG serta data harga sahamnya.

Analisis data menggunakan regresi linier berganda. Uji asumsi klasik dilakukan terlebih dahulu sebelum melakukan analisis regresi linier berganda. Uji asumsi klasik yang digunakan meliputi uji normalitas, uji multikolinearitas, uji heterokedasitas dan uji autokolerasi. Teknik analisis data yang digunakan dalam penelitian ini dirumuskan sebagai berikut: 
$\mathrm{ERC}=\alpha+\beta_{1} \mathrm{KSV}+\beta_{2} \mathrm{GCG}+\beta_{3} \mathrm{GROWTH}+\mathrm{e}$

Keterangan:

$\begin{array}{ll}\text { ERC } & =\text { earnings response coefficient } \\ \alpha & =\text { konstan } \\ \beta_{1,}, \beta_{2}, \beta_{3} & =\text { koefisien regresi } \\ \text { KSV } & =\text { konservatisme akuntansi } \\ \text { GCG } & =\text { good corporate governance } \\ \text { GROWTH } & =\text { pertumbuhan perusahaan } \\ \mathrm{e} & =\text { variabel pengganggu }\end{array}$

Uji koefisien determinasi dilakukan untuk mengetahui seberapa besar variabel independen dapat menjelaskan variasi variabel dependennya, sedangkan sisanya dijelaskan oleh variabel lain di luar penelitian. Uji $\mathrm{F}$ digunakan untuk menguji kelayakan model regresi yang digunakan, sehingga nilai koefisien regresi secara bersama-sama dapat diketahui. Uji t digunakan untuk menguji apakah variabel independen secara parsial berpengaruh terhadap variabel dependen.

\section{HASIL DAN PEMBAHASAN}

Statistik deskriptif digunakan untuk mendeskripsikan variabel-variabel yang digunakan dalam penelitian ini. Hasil uji statistik deskriptif dapat dilihat pada Tabel 1. berikut.

Tabel 1.

Statistik Deskriptif

\begin{tabular}{lcrrrr}
\hline & N & Minimum & Maximum & Mean & Std. Deviation \\
\hline Konservatisme & 30 & $-0,069$ & 2,435 & 0,172 & 0,537 \\
GCG & 30 & 0,836 & 0,932 & 0,870 & 0,026 \\
Growth & 30 & $-0,100$ & 0,820 & 0,164 & 0,154 \\
ERC & 30 & $-0,583$ & 0,485 & 0,018 & 0,190 \\
\hline Sumber: Data diolah, 2018 & & & &
\end{tabular}

Berdasarkan Tabel 1. di atas dapat diketahui bahwa jumlah observasi (N) sebanyak 30. Variabel ERC memiliki nilai maksimum yaitu 0,485, nilai tersebut 
Ni Made Aristawati dan Ni Ketut Rasmini. Pengaruh...

terdapat pada PT. Bank Tabungan Negara (BBTN) tahun 2012, sedangkan nilai minimumnya yaitu $-0,583$ terdapat pada BBTN tahun 2011. ERC memiliki ratarata (mean) sebesar 0,018 yang berarti bahwa rata-rata respon yang diberikan investor terhadap perubahan yang terjadi pada laba perusahaan sampel adalah positif sebesar 0,018. Deviasi standar untuk ERC adalah 0,190 menunjukkan adanya penyimpangan nilai ERC terhadap nilai rata-ratanya sebesar 0,190.

Konservatisme akuntansi memiliki nilai maksimum yaitu 2,435 yang terdapat pada BBTN tahun 2012, sedangkan nilai minimumnya yaitu $-0,069$ pada PT Bank Rakyat Indonesia (BBRI) tahun 2012. Konservatisme akuntansi memiliki rata-rata (mean) 0,172 menunjukkan rata-rata penerapan konservatisme akuntansi positif sebesar 0,172. Deviasi standar konservatisme akuntansi adalah 0,537 menunjukkan adanya penyimpangan nilai konservatisme akuntansi terhadap nilai rata-ratanya sebesar 0,537 .

GCG memiliki nilai maksimum yaitu 0,932 pada PT Bank Mandiri (BMRI) tahun 2015, sedangkan nilai minimumnya yaitu 0,836 pada PT Jasa Marga (JSMR) tahun 2011. GCG mempunyai rata-rata (mean) 0,870 mengungkapkan rata-rata GCG yang menggunakan rata-rata skor CGPI positif sebesar 0,870. Deviasi standar GCG adalah 0,026 menunjukkan adanya penyimpangan nilai GCG terhadap nilai rata-ratanya sebesar 0,026.

Pertumbuhan perusahaan mempunyai nilai maksimum sebesar 0,820 yang terdapat pada JSMR tahun 2012, sedangkan nilai minimum sebesar $-0,100$ terdapat pada JSMR tahun 2014. Pertumbuhan perusahaan memiliki rata-rata (mean) sebesar 0,164 menunjukkan rata-rata pertumbuhan perusahaan positif 
sebesar 0,163. Deviasi standar pertumbuhan perusahaan adalah 0,154 menunjukkan adanya penyimpangan nilai pertumbuhan perusahaan terhadap nilai rata-ratanya sebesar 0,026 .

Uji normalitas dilakukan untuk menguji apakah dalam sebuah model regresi, residu dari persamaan regresi berdistribusi normal atau tidak. Mendeteksi normalitas data dilakukan uji Kolmogorof Smirnov (K-S), jika nilai Asymp.Sig. (2-tailed) lebih besar dari $\alpha=5 \%$ sehingga disimpulkan data terdistribusi normal. Hasil uji Kolmogorof Smirnov dapat dilihat pada Tabel 2. dibawah.

Tabel 2.

Hasil Uji Normalitas

\begin{tabular}{lr}
\hline & Unstandardized Residual \\
\hline $\mathrm{N}$ & 30 \\
Asymp. Sig. (2-tailed) & 0,053 \\
\hline Sumber: Data diolah, 2018 &
\end{tabular}

Tabel 2. Menunjukkan taraf signifikansinya adalah 0,053. Taraf signifikansi diatas 0,05 hal ini berarti model regresi pada penelitian ini berdistribusi normal.

Uji multikolinearitas bertujuan untuk mengetahui hubungan yang bermakna (korelasi) antara setiap variabel bebas (independen) dalam suatu model regresi. Model regresi dikatakan baik apabila tidak terjadi korelasi di antara variabel independen. Hasil uji multikolinearitas dapat dilihat pada Tabel 3. dibawah. 
Tabel 3.

Hasil Uji Multikolinearitas

\begin{tabular}{|c|c|c|}
\hline \multirow{2}{*}{ Model } & \multicolumn{2}{|c|}{ Collinearity Statistics } \\
\hline & Tolerance & VIF \\
\hline Konservatisme & 0,962 & 1,039 \\
\hline GCG & 0,968 & 1,033 \\
\hline Growth & 0,994 & 1,006 \\
\hline
\end{tabular}

Sumber: Data diolah, 2018

Berdasarkan Tabel 3. terlihat bahwa hasil uji multikolinearitas menunjukan nilai tolerance $>0,10$ dan nilai VIF $<10$. Hasil tersebut menyatakan model regresi tidak terjadi korelasi di antara variabel independen.

Hasil uji heteroskedasitas yang digunakan apakah dalam model regresi terjadi ketidaksamaan variance dari residual satu pengamatan ke pengamatan yang lain. Model regresi yang baik seharusnya tidak terjadi heteroskedasitas. Hasil uji heteroskedasitas dengan uji Glesjer. Metode ini dilakukan dengan meregresi nilai absolute residual terhadap variabel bebas. Hasil uji heteroskedasitas dapat dilihat pada Tabel 4. dibawah.

Tabel 4.

\section{Hasil Uji Heteroskedasitas}

\begin{tabular}{lc}
\hline Model & Sig. \\
\hline 1 (Constant) & 0,518 \\
Konservatisme & 0,665 \\
GCG & 0,594 \\
Growth & 0,847 \\
\hline
\end{tabular}

Sumber: Data diolah, 2018

Berdasarkan Tabel 4. tidak terjadi heteroskedasitas, hal ini dikarenakan probabilitas signifikansinya di atas $5 \%$.

Uji autokorelasi bertujuan untuk menguji apakah dalam dalam model regresi linear ada korelasi antara kesalahan pengganggu pada periode $t$ dengan kesalahan pengganggu pada periode t-1 (sebelumnya). Pada lampiran 9, diketahui 
nilai Durbin-Watson adalah 1,862. Nilai du untuk jumlah sampel 30 dengan 3 variabel bebas adalah 1,65. Maka autokolerasinya sebesar $\mathrm{du}<\mathrm{d}<4$-du yaitu $1,65<1,862<2,35$, maka tidak ada gejala autokolerasi.

Berdasarkan uji asumsi klasik, diketahui bahwa data dalam penelitian ini terdistribusi dengan normal, bebas dari multikolinearitas dan tidak terjadi heteroskedasitas dan bebas autokolerasi. Selanjutnya dapat dilakukan uji model regresi linier berganda pada Tabel 5. berikut.

Tabel 5.

Hasil Analisis Regresi Linier Berganda

\begin{tabular}{lcrrr}
\hline & \multicolumn{2}{c}{ Unstandardized Coefficients } & & \\
Model & $\mathrm{B}$ & Std. Error & $\mathrm{t}$ & \multicolumn{1}{c}{ Sig. } \\
\hline 1 (Constant) & $-0,127$ & 1,012 & $-0,126$ & 0,901 \\
KSV & 0,210 & 0,057 & 3,677 & 0,001 \\
GCG & 0,107 & 1,159 & 0,093 & 0,927 \\
Growth & 0,094 & 0,196 & 0,480 & 0,635 \\
R Square & & & & 0,348 \\
Adjusted R Square & & & & 0,273 \\
F Hitung & & & & 4,630 \\
Sig. F & & & & 0,010 \\
\hline Sumber: Data diolah, 2018 & & &
\end{tabular}

Nilai konstanta $(\alpha)$ sebesar $-0,127$ persen. Ini menyatakan bahwa jika variabel konservatisme akuntansi, good corporate governance dan pertumbuhan perusahaan konstan, maka nilai earnings response coefficient sebesar -0,127 persen.

Nilai koefisien regresi konservatisme akuntansi $\left(\beta_{1}\right)$ yaitu 0,210 persen artinya apabila konservatisme akuntansi meningkat sebesar 1 persen dengan asumsi variabel lainnya konstan, maka earnings response coefficient akan mengalami kenaikan sebesar 0,210 persen. Tingkat signifikansi 0,001 lebih kecil 
Ni Made Aristawati dan Ni Ketut Rasmini. Pengaruh...

dari $\alpha=0,05$. Hal ini menunjukkan bahwa konservatisme akuntansi berpengaruh pada earnings response coefficient. Dengan demikian maka $\mathrm{H}_{1}$ diterima.

Nilai koefisien regresi good corporate governance $\left(\beta_{2}\right)$ yaitu sebesar 0,107 persen artinya apabila good corporate governance meningkat sebesar 1 persen dengan asumsi variabel lainnya konstan, maka earnings response coefficient akan mengalami kenaikan sebesar 0,107 persen. Tingkat signifikansinya adalah 0,927 lebih besar dari $\alpha=0,05$. Hal ini menunjukkan good corporate governance tidak berpengaruh pada earnings response coefficient. Dengan demikian maka $\mathrm{H}_{2}$ ditolak.

Nilai koefisien regresi pertumbuhan perusahaan $\left(\beta_{3}\right)$ yaitu sebesar 0,094 persen artinya apabila pertumbuhan perusahaan meningkat sebesar 1 persen dengan asumsi variabel lainnya konstan, maka earnings response coefficient akan mengalami kenaikan sebesar 0,094 persen. Tingkat signifikansi adalah 0,635 lebih besar dari $\alpha=0,05$. Hal tersebut mengungkapkan pertumbuhan perusahaan tidak berpengaruh pada earnings response coefficient. Dengan demikian maka $\mathrm{H}_{3}$ ditolak.

Berdasarkan Tabel 5. nilai Adjusted R Square sebesar 0,273 atau 27,3 persen, artinya respon pasar dapat dijelaskan oleh konservatisme akuntansi, Good Corporate Governance dan pertumbuhan perusahaan sebesar 27,3 persen. Sejumlah 72,7 persen dijelaskan oleh variabel-variabel lain yang tidak masuk dalam penelitian. Nilai $\mathrm{F}$ dalam penelitian ini sebesar 0,010 lebih kecil dari taraf signifikansi 0,05. Oleh karena itu, secara bersama-sama (simultan) variabel 
konservatisme akuntansi, Good Corporate Governance dan pertumbuhan perusahaan mempengaruhi earnings response coefficient.

Hipotesis pertama menyatakan bahwa konservatisme akuntansi berpengaruh positif pada earnings response coefficient. Hasil analisis menunjukkan konservatisme akuntansi berpengaruh pada earnings response coefficient. Arah koefisien konservatisme akuntansi dalam penelitian ini bertanda positif yang berarti semakin tinggi konservatisme akuntansi pada perusahaan maka earnings response coefficient akan semakin meningkat. Penelitian ini mendukung teori sinyal dimana konservatisme akuntansi berperan dalam teori sinyal dengan mencegah asimetri informasi dengan menyajikan laba yang tidak overstated. Sinyal sebagai dorongan perusahaan untuk memberikan informasi kepada pihak eksternal dapat meminimalisir kesalahan atau kekeliruan dalam berinvestasi serta tidak salah menafsirkan informasi laba perusahaan. Hasil penelitian ini mendukung penelitian yang telah dilakukan oleh Tuwentina \& Wirama (2014), Rahayu (2012), dan Setyaningtyas (2009) yang menyatakan bahwa konservatisme akuntansi berpengaruh positif pada earnings response coefficient. Berdasarkan uraian tersebut maka hipotesis pertama diterima.

Hipotesis kedua menyatakan bahwa good corporate governance berpengaruh positif pada earnings response coefficient. Temuan analisis menyatakan good corporate governance tidak berpengaruh pada earnings response coefficient. Tidak berpengaruhnya good corporate governance yang diukur dengan menggunakan pemeringkatan yang dilakukan oleh IICG dari tahun 2011 sampai tahun 2015 pada earnings response coefficient dikarenakan 
Ni Made Aristawati dan Ni Ketut Rasmini. Pengaruh...

pengumuman earnings yang dilakukan oleh perusahaan yang bagus corporate governance-nya tidak secara signifikan meningkatkan value relevance dalam pengumuman earnings. Hal ini disebabkan oleh sebagian perusahaan yang masuk peringkat IICG pada saat itu mengalami penurunan EPS terutama perusahaan yang tingkat CGPI-nya bagus sehingga terlihat bahwa kinerja perusahaannya buruk dan berpengaruh pada penilaian investor. GCG penerapannya juga tidak bersifat jangka pendek sedangkan dalam menghitung profitabilitasnya memiliki sifat jangka pendek, jika menggunakan satu periode akuntansi, penerapan GCG tidak dapat diukur keberhasilannya.

Hasil ini bertentangan dengan teori sinyal dimana perusahaan yang menerapkan GCG serta mengikuti pemeringkatan IICG seharusnya dapat meningkatkan respon pasar namun hasil ini menunjukkan good corporate governance tidak berpengaruh pada earnings response coefficient. Temuan penelitian ini sejalan dengan penelitian yang telah dilakukan oleh Tuwentina \& Wirama (2014) yang menemukan bahwa good corporate governance tidak berpengaruh pada kualitas laba yang pengukurannya menggunakan ERC. Berdasarkan uraian tersebut maka hipotesis kedua ditolak.

Hipotesis ketiga menyatakan bahwa pertumbuhan perusahaan berpengaruh positif pada earnings response coefficient. Hasil analisis mengungkapkan pertumbuhan perusahaan tidak berpengaruh pada earnings response coefficient. Tidak adanya pengaruh pertumbuhan perusahaan diukur melalui pertumbuhan penjualan perusahaan dikarenakan pertumbuhan penjualan tidak stabil. Beberapa perusahaan mengalami pertumbuhan penjualan yang tinggi kemudian mengalami 
penurunan. Selain itu situasi perekonomian saat penelitian membuat investor low risk averse sehingga adanya penjualan saham yang besar, hal ini menyebabkan harga saham menurun, untuk investor yang high risk averse akan melakukan pembelian saham

Hasil penelitian tersebut bertentangan dari teori sinyal dimana pertumbuhan perusahaan seharusnya dapat meningkatkan ERC namun hasil ini menunjukkan pertumbuhan perusahaan tidak berpengaruh pada ERC. Hasil penelitian ini sejalan dengan penelitian yang telah dilakukan oleh Listyawan (2017), Dira \& Astika (2014) serta Irawati (2012) yang menyatakan bahwa pertumbuhan perusahaan tidak berpengaruh terhadap ERC. Berdasarkan uraian tersebut maka hipotesis ketiga ditolak.

Implikasi dari penelitian ini dibagi menjadi dua diantaranya implikasi teoritis dan implikasi praktis. Implikasi teoritis menunjukkan hasil penelitian ini tidak mengkonfirmasi teori sinyal yang menyatakan bahwa mekanisme yang diharapkan dapat memberikan sinyal terhadap pihak yang berkepentingan yaitu dengan menerapkan GCG serta perusahaan yang bertumbuh dapat menjadi sinyal bagi investor dalam keputusan investasi. GCG dan pertumbuhan perusahaan secara empiris tidak berpengaruh pada ERC. Besar kecilnya presentase GCG dan pertumbuhan perusahaan tidak akan mempengaruhi ERC.

Hasil penelitian ini mengkonfirmasi teori sinyal yang menyatakan bahwa sinyal sebagai dorongan perusahaan untuk memberikan informasi kepada pihak eksternal. Signaling Theory menunjukkan adanya asimetri informasi antara manajemen dengan pihak-pihak yang berkepentingan dengan informasi tertentu. 
Ni Made Aristawati dan Ni Ketut Rasmini. Pengaruh...

Hal ini dapat ditunjukkan dengan menerapkan konservatisme akuntansi yang berperan dalam teori sinyal dengan mencegah asimetri informasi melalui penyajian laba yang tidak overstated. Konservatisme akuntansi secara empiris berpengaruh pada ERC sehingga semakin besar penerapan konservatisme akuntansi pada suatu perusahaan maka nilai ERC semakin tinggi. Penelitian ini mengungkapkan dimana tidak semua variabel penelitian secara teori mempengaruhi earnings response coefficient. Hasil penelitian secara nyata tidak membuktikan secara keseluruhan dikarenakan adanya perbedaan kondisi, periode serta obyek penelitian.

Penerapan atau implikasi praktisnya dapat digunakan sebagai kontribusi bagi penyempurnaan penelitian selanjutnya, sebagai tambahan informasi bagi pihak yang berkepentingan, seperti perusahaan diharapkan dapat meningkatkan kualitas labanya dalam rangka meningkatkan kinerja dan nilai perusahaan. Selain itu, pihak perusahaan juga diharapkan dapat mengikuti pemeringkatan yang dilakukan IICG, karena perusahaan yang mengikuti pemeringkatan tersebut setiap tahunnya tidak perusahaan yang sama dan hanya sebagian kecil dari keseluruhan perusahaan tersebut di BEI. Serta bagi pihak investor dalam berinvestasi tetap memperhatikan kualitas laba sebagai pertimbangan analisis pertumbuhan, risk dan returnnya, sebagai analisis kebutuhan sumber pendanaan perusahaan.

\section{SIMPULAN DAN SARAN}

Berdasarkan hasil penelitian maka dapat disimpulkan bahwa konservatisme akuntansi berpengaruh positif pada Earnings Response Coefficient, Good Corporate Governance tidak berpengaruh pada Earnings Response Coefficient 
dan pertumbuhan perusahaan tidak berpengaruh pada Earnings Response Coefficient. Berdasarkan hasil penelitian dan simpulan maka saran yang dapat disampaikan adalah peneliti selanjutnya diharapkan dapat lebih menyempurnakan penelitian ini dengan menggunakan tidak hanya perusahaan yang masuk pemeringkatan oleh IICG saja tetapi lebih kepada substansinya.

Kelemahan pada penelitian ini adalah penelitian ini hanya dilakukan pada perusahaan yang masuk pemeringkatan yang dilakukan oleh IICG saja. Peneliti selanjutnya diharapkan menggunakan periode yang lebih panjang agar pengukuran terhadap earnings response coefficient bisa lebih akurat. Penggunaan pengukuran variabel bebas yang lain, seperti Investment Opportunity Set, ukuran perusahaan, opini auditor.

\section{REFERENSI}

Ahmed, A. S., R. M. Morton, \& T. F. Schaefer. (2000). Accounting Conservatism and the Valuation of Accounting Number: Evidence on the FelthamOhlson (1996) Model. Journal of Accounting, Auditing \& Finance 15.

Astika, Putra. (2011). Konsep-konsep Dasar Akuntansi Keuangan. Udayana University Press: Denpasar.

Ball, R., \& P. Brown, (1968). An Empirical Evaluation on Accounting Income Number. Journal of Accounting Research.

Bistrova, Julia \& Natalia Lace. (2012). Quality of Corporate Governance System and Quality of Reported Earnings: Evidence From CEE Companies. Journal of Economic and Management, 17(1).

Chaney, P,K, \& Jeter, D,C. (1991). The Effect of Size on the Magnitude of LongWindow Earnings Response Coefficient. Contemporary Accounting Research, 8, 540-560.

Charitou, A., C. Clubb \& A. Andreao. (2001). "The Effects of Earnings Permanence, Growth, and Firm Size on the Usefullness of Cash Flows and 
Earnings in Explaining Security Returns: Empirical Evidence for the UK". Journal of Business Finance and Accounting, 563-594.

Collins D.W., M. Pincus \& S.P. Kothari. (1989). "An Analysis of Intertemporal and Cross-Sectional Determinants of Earnings Response Coefficients". Journal of Accounting and Economics 11, 143-181.

Cho, J.Y \& K. Jung. (1991). Earnings Response Coefficient: A Sythesis of Theory and Empirical Evidence. Journal of Accounting.

Collins D.W., M. Pincus \& S.P. Kothari. (1989). “An Analysis of Intertemporal and Cross-Sectional Determinants of Earnings Response Coefficients". Journal of Accounting and Economics 11, 143-181.

Diantimala, Yossi. (2008). Pengaruh Akuntansi Konservatif, Ukuran Perusahaan, dan Default Risk terhadap Koefisien Respon Laba (ERC). E-journal Akuntansi Universitas Syiah Kuala, 1(1), 102-122.

Indrawati, Novita, \& Yulianti, Lilla. (2010). Mekanisme Corporate Governance dan Kualitas Laba. Pekbis Jurnal, 2(2), 283-291.

Irawati, Dhian Eka. (2012). Pengaruh Struktur Modal, Pertumbuhan, Ukuran Perusahaan dan Likuiditas Terhadap Kualitas Laba. Accounting Analysis Journal, ISSN:2252-6765.

Kartadjumena, Eriana. (2010). Pengaruh Voluntary Disclosure of Financial Information dan CSR Disclosure Terhadap Earning Response Coefficient. http://dspace.widyatama.ac.id. Diakses 15 Oktober 2017.

Kori, Made Opyandari Dharsini \& Ni Ketut Rasmini. (2017). Struktur Good Corporate Governance sebagai Pemoderasi Pengaruh Asimetri Informasi pada Manajemen Laba. E-Jurnal Akuntansi Universitas Udayana. 21(1), 144-172.

Lev, Baruch. (1989). One the Usefulness of Earnings and Earnings Research: Lessons and Directions from Two Decades of Empirical Research. Journal of Accounting Research, 27, 153-192.

Murwaningsari. (2008). Pengujian Simultan: Beberapa Faktor yang Mempengaruhi Earnings Response Coefficient (ERC). Simposium Nasional Akuntansi XI, Pontianak.

Naimah Zahroh \& Siddharta Utama. (2006). Pengaruh Ukuran Perusahaan, Pertumbuhan dan Profitabilitas Perusahaan Terhadap Koefisien Respon Laba dan Koefisien Nilai Buku Ekuitas: Studi pada Perusahaan Manufaktur di BEJ. Simposium Nasional Akuntansi, Padang. 
Natalia, Desriyana \& Ni Made Dwi Ratnadi. (2017). Pengaruh Konservatisme Akuntansi dan Leverage pada Earnings Response Coefficient. E-journal Akuntansi Universitas Udayana, 20(1), 61-86.

Nayar, Nandkumar \& Michael S. Rozeff. (1992). Earnings Response Coefficient Models: Synthesis and Extensions.

Neal, Robert \& Philip L. Cochran. (2008). Corporate Social Responsibility, Corporate Governance, and Finance Performance: Lesson from Finance, Bussines Horizon, 51, 535-540.

Palupi, Margaretta J. (2006). Analisis Faktor-Faktor yang Mempengaruhi Koefiien Respon Laba. Jurnal Ekubank. (3).

Park, Chul W. \& Morton Pincus. (2001). Internal Versus External Equity Funding Sources and Earnings Response Coefficients. Working Paper. SSRN.

Penman, S.H, \& Zhang, X.J. (2002). Accounting Conservatism, the Quality of Earnings, and Stock Returns. The Accounting Review, 77, 237-264.

Putri, I G.A Intan Pancali. (2015). Pengaruh Leverage, Systematic Risk, Growth Opportunities dan Firm Size pada Earnings Response Coefficient. Skripsi Sarjana Jurusan Akuntansi pada Fakultas Ekonomi dan Bisnis Universitas Udayana, Denpasar.

Rahayu, Siti. (2012). Pengaruh Konservatisma Laba Terhadap Koefisien Respon Laba pada Perusahaan Manufaktur yang Terdaftar di BEI. http://digilib.unimed.ac.id. Diakses pada 16 Oktober 2017.

Rahayu, Sovi Ismawati. (2008). Pengaruh Tingkat Ketaatan Pengungkapan Wajib Dan Luas Pengungkapan Sukarela Terhadap Kualitas Laba. Simposium Nasional Akuntansi VIII Solo, 136-146.

Ratna, Dewi A.A.A. (2004). Pengaruh Konservatisme Laporan Keuangan Terhadap Earnings Response Coefficient. Jurnal Riset Akuntansi Indonesia, 7(2), 207-223.

Ratnadi, Dwi Ni Made \& I G. K. A Ulupui. (2016). Pengaruh Konsentrasi Kepemilikan dan Kompetesi Dewan Komisaris pada Konservatisme Akuntansi pada Konservatisma Akuntansi. Jurnal Akuntansi, 20(1), 1-15.

Reyhan, Arief. (2014). Pengaruh Komite Audit, Asimetri Informasi, Ukuran Perusahaan, Pertumbuhan Laba dan Profitabilitas Terhadap Kualitas Laba. Journal of Accounting and Economics, 1(2). 
Rifani, Aulia. (2013). Pengaruh Good Corporate Governance terhadap Hubungan Manajemen Laba dan Kualitas Laba. Skripsi Sarjana Program Studi Akuntansi pada Fakultas Ekonomi Universitas Negeri Padang, Padang.

Sari, Intan Puspita A.A \& I G. A. M. Asri Dwija Putri. (2014). Pengaruh Mekanisme Corporate Governance pada Manajemen Laba. E-journal Akuntansi Universitas Udayana, 8(1), 94-104.

Sari, Rizkia Anggita. (2012). Pengaruh Karakteristik Perusahaan Terhadap Corporate Social Responsibility Disclosure pada Perusahaan Manufaktur yang Terdaftar di Bursa Efek Indonesia. Jurnal Nominal, 1(1).

Sayekti, Y \& Wondabio, L. S. (2007). Pengaruh Corporate Social Responsibility Disclosure terhadap Earnings Respon Coefficient (Suatu Studi Empiris pada Perusahaan yang Terdaftar di Bursa Efek Jakarta). Simposium Nasional Akuntansi IX Makasar.

Setiawati, Erma \& Nursiam. (2014). Analisis Pengaruh Ukuran, Pertumbuhan dan Profitabilitas Perusahaan Terhadap Koefisien Respon Laba. Research Methods and Organizational Studies. Fakultas Ekonomi dan Bisnis Universitas Muhammadiyah, Surakarta, 175-188.

Setyaningtyas, Tara. (2009). Pengaruh Konservatisme Laporan Keuangan dan Siklus Hidup Perusahaan terhadap Koefisien Respon Laba. Skripsi Sarjana Jurusan Akuntansi pada Fakultas Ekonomi Universitas Sebelas Maret, Surakarta.

Scott, William R. (2009). Financial Accounting Theory, $5^{\text {th }}$ Ed. Canada: Prentice Hall Inc. Ontario.

Spence, M. (1973). Job Market Signaling. The Quarterly Journal of Economis, 87(3): pp:355-374.

Suaryana, Agung. (2005). Pengaruh Komite Audit Terhadap Kualitas Laba. Simposium Nasional Akuntansi VIII, Ikatan Akuntan Indonesia, KAKPM 07.

Sugiarto, Jang L. B. dan D. Siagian. (2007). Faktor-Faktor yang Mempengaruhi Kualitas Laba pada Perusahaan Manufaktur di BEJ. Journal of Accounting and Economic, 6(2), 142-149.

Tuwentina, Putu \& Dewa Gede Wirama. (2014). Pengaruh Konservatisme Akuntansi dan Good Corporate Governance terhadap Kualitas Laba. Ejournal Akuntansi Universitas Udayana, 8(2), 185-201. 
Wati, Gahani Purnama \& I Wayan Putra. (2017). Pengaruh Ukuran Perusahaan, Leverage, dan Good Corporate Governance pada Kualitas Laba. Skripsi Sarjana Jurusan Akuntansi pada Fakultas Ekonomi dan Bisnis Universitas Udayana, Bali.

Wulandari. I A. Triesni \& Bambang Herkulanus Suprasto. (2015). Konservatisme Akuntansi, Good Corporate Governance dan Pengungkapan Corporate Social Responsibility pada Earnings Respons Coefficient. E-journal Akuntansi Universitas Udayana, 3(1), 173-190. 